Intensities of the lines should permit examination of further isotopic forms, and work on this is continuing in order to allow completion of the structure determination. It may be noted, however, that, if the $-\mathrm{CH}_{2} \mathrm{CN}$ group were assigned a structure close to that in methyl cyanide ${ }^{1}$, the constants so far measured would require a carbon-fluorine distance of about $1.38 \AA$., and an angle FCC near $111^{\circ}$. The present results are thus compatible with a carbon-fluorine distance similar to that in methyl fluoride ${ }^{2}$, and a carbon-carbon distance similar to that in methyl cyanide. Definite conclusions, however, must await further measurements.

We thank the Department of Scientific and Industrial Research for a research studentship awarded to one of us (B. E. J.).

B. E. Јов

J. SHERIDAN

Department of Chemistry,

The University,

Birmingham, 15.

${ }^{1}$ Thomas, L. F., Sherrard, E. I., and Sheridan, J., Trans. Frarad. Soc., 51, 619 (1955).

${ }^{2}$ Andersen, F. A., Bak, B., and Brodersen, S., J. Chem. Phys., 24, $989(1956)$.

\section{Rubeanic Acid as Stabilizer of Aqueous Solutions of Ascorbic Acid}

Especiatly noteworthy among the stabilizers of ascorbic acid solutions are sulphydric organic derivatives such as glutathione, thiourea, methylthiouracyl,

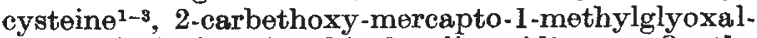
ine $^{2,3}$, dithioglycerin, thioglycolic acid ${ }^{2}$, ete. On the other hand, acids have found application as agents reducing the rate of oxidation of ascorbic acid in solutions. Among these oxalic acid plays an important part. In 2 per cent and 1 per cent dilutions it is applied as a stabilizer of synthetic ascorbic acid in various solutions and of ascorbic acid in biological material.

This suggested the use of rubeanic acid for preventing oxidation of ascorbio acid in aqueous solution. Rubeanic acid is a diamide of thio-oxalic acid. We wanted to investigate the stability of 0.01 per cent aqueous solution of ascorbic acid in the presence of rubeanic acid.

Ascorbic acid solutions containing rubeanic acid were prepared, and the ascorbic acid content was assessed during storage. Moreover, the same solutions were subjected to the effect of oxidizing factors, such as irradiation with a quartz lamp or introduction of cupric ions, the ascorbic acid content being measured all the time. This was earried out by means of Tillmann's method, consisting in the reduction of 2,6-dichlorphenolindophenol. Table 1 shows results obtained in determining the stability of ascorbic in rubeanic acid solutions.

Table 1. STABeuty OF 0.01 PER OENT AQUEOUS SOLUTION OF AsCoRBIC AcId IN The PResendoe of RUBeanio Acid

\begin{tabular}{|c|c|c|c|}
\hline $\begin{array}{c}\text { Time of } \\
\text { storage (hr.) }\end{array}$ & $\begin{array}{l}\text { Ascorbic acic } \\
\text { in aqueous } \\
\text { solution }\end{array}$ & $\begin{array}{c}\text { intent (per cent o } \\
\text { in } 01 \text { per cent } \\
\text { rubeanic acid }\end{array}$ & $\begin{array}{l}\text { f initial content) } \\
\text { in } 0 \cdot 001 \text { per cent } \\
\text { rubeanic acid }\end{array}$ \\
\hline $\begin{array}{r}\overline{0.5} \\
1 \cdot 0 \\
2 \cdot 0 \\
3 \cdot 0 \\
4 \cdot 0 \\
23.0\end{array}$ & $\begin{array}{r}100 \cdot 0 \\
82.0 \\
49 \cdot 9 \\
33 \cdot 3 \\
16 \cdot 6 \\
13 \cdot 3 \\
0.0\end{array}$ & $\begin{array}{r}100 \cdot 0 \\
99 \cdot 2 \\
98 \cdot 3 \\
98 \cdot 3 \\
97 \cdot 6 \\
97 \cdot 6 \\
92 \cdot 8\end{array}$ & $\begin{array}{r}100 \cdot 0 \\
98 \cdot 3 \\
97 \cdot 6 \\
96 \cdot 0 \\
96 \cdot 0 \\
94 \cdot 4 \\
80.0\end{array}$ \\
\hline
\end{tabular}

In Table 2 are assembled the results obtained in assessing the stability of ascorbic acid solutions irradiated with a quartz lamp.

Table 2. Stability of 0.01 Per Cent AqueOUs Solution of Ascorbic ACID IN THE PRESENCE OF RUBEATIC ACID ON IRRADIATION WITH A

\begin{tabular}{|c|c|c|}
\hline \multirow{2}{*}{$\begin{array}{c}\text { Time of storage } \\
(\mathbf{h r} .)\end{array}$} & \multicolumn{2}{|c|}{$\begin{array}{l}\text { Ascorbic acid content } \\
\text { (percentage of initial content) }\end{array}$} \\
\hline & in aqueous solution & $\begin{array}{l}\text { in } 0.01 \text { per cent } \\
\text { rubeanic acid }\end{array}$ \\
\hline $\begin{array}{l}-\overrightarrow{0 \cdot 5} \\
1 \cdot 0 \\
2 \cdot 0 \\
3 \cdot 0 \\
4 \cdot 0\end{array}$ & $\begin{array}{r}100 \cdot 0 \\
69 \cdot 7 \\
51 \cdot 3 \\
21 \cdot 0 \\
9 \cdot 1 \\
3 \cdot 3\end{array}$ & $\begin{array}{r}100 \cdot 0 \\
98 \cdot 3 \\
98 \cdot 3 \\
98 \cdot 3 \\
97 \cdot 6 \\
97 \cdot 6\end{array}$ \\
\hline
\end{tabular}

Table 3 shows the ascorbic acid content in 0.01 per cent and 0.001 per cent solutions of rubeanic acid in the presence of copper ions $(0.001$ per cent and 0.0001 per cent copper sulphate).

Table 3. Stabinty of Ascorbic ACID IN 0.01 PER Cent Solumon, in the Presence of RUbeanic ACID aNd ON ADmixturg of

\begin{tabular}{|c|c|c|c|c|c|}
\hline \multirow{4}{*}{$\begin{array}{l}\text { Time of } \\
\text { storage } \\
\text { (hr.) }\end{array}$} & \multicolumn{5}{|c|}{ Ascorbic acid content (percentage of initial content) } \\
\hline & in 0.001 & in $\begin{array}{c}0.01 \\
\text { rubea }\end{array}$ & $\begin{array}{l}\text { oer cent } \\
\text { c acid }\end{array}$ & $\begin{array}{l}\text { in } 0.00 \\
\text { rube }\end{array}$ & $\begin{array}{l}\text { per cent } \\
\text { je acid }\end{array}$ \\
\hline & per cent & in 0.001 & in 0.0001 & in 0.001 & in 0.0001 \\
\hline & $\mathrm{CuSO}_{4}$ & $\begin{array}{l}\text { per cent } \\
\text { CuSO }_{4}\end{array}$ & $\begin{array}{c}\text { per cent } \\
\text { CuSO }_{4}\end{array}$ & $\begin{array}{c}\text { per cent } \\
\text { CuSO, }\end{array}$ & $\begin{array}{c}\text { per cent } \\
\text { CuSO }_{4}\end{array}$ \\
\hline \multirow{7}{*}{$\begin{array}{r}\overline{0 \cdot 5} \\
1 \cdot 0 \\
2 \cdot 0 \\
3 \cdot 0 \\
4 \cdot 0 \\
24 \cdot 0 \\
48 \cdot 0\end{array}$} & \multirow{7}{*}{$\begin{array}{r}100 \cdot 0 \\
10 \cdot 0 \\
0.0 \\
= \\
= \\
=\end{array}$} & \multirow{7}{*}{$\begin{array}{r}100 \cdot 0 \\
99 \cdot 0 \\
99 \cdot 0 \\
98.1 \\
95.8 \\
93.4 \\
80.0\end{array}$} & \multirow{7}{*}{$\begin{array}{r}100 \cdot 0 \\
99 \cdot 3 \\
99 \cdot 3 \\
98 \cdot 4 \\
96 \cdot 5 \\
96 \cdot 9 \\
86.3\end{array}$} & $100 \cdot 0$ & $100 \cdot 0$ \\
\hline & & & & 98.3 & 100.0 \\
\hline & & & & $97 \cdot 4$ & $99 \cdot 2$ \\
\hline & & & & $91 \cdot 2$ & $98-3$ \\
\hline & & & & $91 \cdot \overline{2}$ & $96 \cdot 6$ \\
\hline & & & & 91.2 & \\
\hline & & & & 66.9 & $72 \cdot 3$ \\
\hline
\end{tabular}

From the results in Tables 1-3 rubeanic acid is seen to be a stabilizer of ascorbic acid. The stability of the solutione is dependent on the amount of rubeanic acid added. Ultra-violet radiation and copper ions in solution, which are factors accelerating the oxidation of ascorbic acid, lose their activity in the presence of rubeanic acid.

\section{Institute of Inorganic and \\ Analytical Chemistry, Medical Academy,}

Aleksandra SMOCZKrEwICZOWA JANINA Grochmaticka

Poznań, Poland.

${ }^{3}$ Drevon, B., Nofre, C., and Cier, C., Ann. Pharm. Franc., 16, 495 (1958).

2 Feldheim, W., and Seldemann, J., Pharmazie, 14, 12 (1959).

${ }^{3}$ Feldheim, W., and Seidemann, J., Pharmazie, 14, 80 (1959).

\section{Ligand Field for Chromic lons in the Corundum Lattice}

RECENT work on absorption spectra and lattice spacings in the $\mathrm{Al}_{2} \mathrm{O}_{3}-\mathrm{Cr}_{2} \mathrm{O}_{3}$ solid solution ${ }^{1-6}$ has been in sufficient agreement to warrant a fitting of the optical results to the crystal field-splitting diagram? ${ }^{2}$. The relevant terms are shown in Fig. 1, which also shows the transitions involved in the yellow and blue absorption bands.

Assuming the Racah parameter $B$ to be constant throughout the system, it is impossible to obtain a fit no matter what value of $B$ is chosen. An example is shown in Fig. 2 , with $B=650 \mathrm{~cm} .^{-1}$. This value was chosen to give a fit at about 5.5 per cent $\mathrm{Cr}_{2} \mathrm{O}_{3}$, where the observed maxima for ruby (Graham ${ }^{1}$ ) and $\mathrm{Cr}\left(\mathrm{H}_{2} \mathrm{O}\right)_{8}{ }^{3+}$ (Tsuchida $\left.{ }^{8}\right)$ are identical. 